\title{
Influence of preferred orientation on the bioactivity of hydroxyapatite: a potential tooth repair and implant surface coating material
}

\author{
(Influência da orientação preferencial na bioatividade da \\ hidroxiapatita: potencial reparo dentário e material de revestimento \\ de superficie de implante)
}

\author{
B. O. Asimeng ${ }^{1 *}$, E. K. Tiburu ${ }^{1}$, K. Kan-Dapaah ${ }^{1}$, J. K. Efavi ${ }^{2}$, R. Asiamah ${ }^{1}$ D. W. Afeke ${ }^{1}$ \\ ${ }^{\prime}$ University of Ghana, Department of Biomedical Engineering, Legon, Ghana \\ ${ }^{2}$ University of Ghana, Department of Materials Science and Engineering, Legon, Ghana
}

\begin{abstract}
Bioactive hydroxyapatite (HAp) material was synthesized using a simple wet chemical precipitation and heat-treatment method from snail (Achatina achatina) shells and a phosphate-containing solution. According to X-ray diffraction patterns obtained, the heat-treatment caused a crystallographic preferred orientation along the HAp c-axis and thus, affected the material mineralization and bioactivity modeled in vitro using simulated body fluid (SBF) for 7 and 21 days. After 21 days of immersion, calcium and phosphate mineral concentrations in SBF decreased by $66 \%$ and $83 \%$, respectively. This corresponded to a transformation from a poor calcium amorphous apatite phase (calcium phosphate) to a resorbing crystalline calcium apatite indicated by scanning electron microscopy micrographs. The material crystallite size $(\sim 15 \mathrm{~nm})$, lattice parameters, physicochemical properties, and morphological characteristics were all typical of the human enamel apatite and, therefore, could be considered ideal for use in tooth repairs and implant surface coatings.
\end{abstract}

Keywords: bioactivity, biomaterial, hydroxyapatite, snail shell.

Resumo

Hidroxiapatita bioativa (HAp) foi sintetizada usando um método simples de precipitação química e tratamento térmico a partir de conchas de caracol (Achatina achatina) e uma solução contendo fosfato. De acordo com os padrões de difração de raios Xobtidos, o tratamento térmico causou orientação cristalográfica preferencial ao longo do eixo c da HAp e, assim, afetou a mineralização e bioatividade do material in vitro usando fluido corporal simulado (SBF) por 7 e 21 dias. Após 21 dias de imersão, concentrações minerais de cálcio e fosfato no SBF diminuíram $66 \%$ e $83 \%$, respectivamente. Isso correspondeu a uma transformação de uma fase de apatita amorfa pobre em cálcio (fosfato de cálcio) em uma apatita cristalina reabsorvível, indicada por micrografias de microscopia eletrônica de varredura. O tamanho do cristalito $(\sim 15 \mathrm{~nm})$, parâmetros de rede, propriedades físico-químicas e as características morfológicas do material foram típicos da apatita do esmalte humano e, portanto, podem ser considerados ideais para uso em reparos de dentes e revestimentos de superficies de implantes.

Palavras-chave: bioatividade, biomaterial, hidroxiapatita, concha de caracol.

\section{INTRODUCTION}

Hydroxyapatite (HAp) is a member of the apatite family with the chemical formula $\mathrm{Ca}_{10}\left(\mathrm{PO}_{4}\right)_{6}(\mathrm{OH})_{2}$. In physiological conditions, HAp is the most thermodynamically stable [1] and thus, promotes new bone ingrowth through osteointegration without causing any inflammation or immunogenic response [2]. The osteointegrative behavior of HAp promotes firm anchorage between an implant and surrounding tissues in the body without the formation of fibrous tissues [3]. As

*boasimeng@ug.edu.gh

Dhttps://orcid.org/0000-0002-4847-450X a result, HAp is considered an ideal bioactive bioceramic material for use in bone and teeth implant surface coatings as well as scaffold designs for bone tissue regeneration [4]. Osteointegration typically depends on the bioactivity of a material, that is, the material's ability to elicit a specific biological response at the interface of the material, which results in the formation of a strong bond between bone and material [5]. Scientific literature reports that substitution of ions like zinc, magnesium, copper, phosphite, and carbonate into HAp results in the formation of HAp with a comparable natural bone resemblance (in terms of composition, structure, and morphology). This thus enhances its bioactivity for a rapid osteointegration instigation [6]. Additionally, the bioactivity results in the formation of a calcium phosphate 
(bioactive apatite) film at the surface of the implant. In dental applications, this apatite film hermetically seals the tooth margin and thereafter, protects the restoration against possible leakage and secondary carriers, thereby prolonging the implant's lifespan [7-9].

The mechanism of the bioactive apatite film formation is through chemical reactions, which include precipitation, nucleation, and growth of calcium phosphate [10]. Upon implantation in the body, the HAp undergoes structural and chemical changes through dissolution. This phenomenon results in the release of calcium ions from the HAp structure into the body fluid and a subsequent increase in the local ion saturation concentration $[11,12]$. The surface becomes increasingly negatively charged due to the presence of hydroxyl and phosphate groups. As the implantation time progresses, the surface begins to attract more positively charged calcium ions from the body fluid, which leads to the formation of calcium-rich amorphous calcium phosphate (Ca-rich ACP) film [13]. The layer interacts with the negative phosphate ions in the body fluid to form calcium-poor amorphous calcium phosphate (Ca-poor ACP) film $[14,15]$. These two films conform to form a crystalline bioactive apatite film.

In the present study, authors have been able to prepare a bioactive material from snail (Achatina achatina) shells and a phosphate containing-solution through heattreatments. The bioactivity was modeled in vitro using simulated body fluid (SBF) at a physiological temperature of $37{ }^{\circ} \mathrm{C}$ [16], and the apatite film determined using a scanning electron microscope (SEM) coupled with an energy-dispersive X-ray spectroscope (EDS).

\section{EXPERIMENTAL}

Starting materials: Achatina achatina (AA) shells were acquired from the Madina market in Ghana, and diammonium hydrogen phosphate $\left[\left(\mathrm{NH}_{4}\right)_{2} \mathrm{HPO}_{4}, 132.06\right.$ $\mathrm{g} / \mathrm{mol}, 98.5 \%]$ was purchased from Kosdag Listed.

Calcite preparation from AA shells: AA shells were thoroughly washed with water to remove all particles and debris, then dried for $6 \mathrm{~h}$ under direct sunlight. The dried shells were crushed into powder using a mortar and pestle. The powder was calcined at $850{ }^{\circ} \mathrm{C}$ for $2 \mathrm{~h}$ to convert the powder from aragonite to calcite [17]. Aragonite and calcite are the two main polymorphs of calcium carbonate $\left(\mathrm{CaCO}_{3}\right)$. Aragonite has an orthorhombic crystal structure and forms at low temperatures on the surface of minerals, while calcite has a trigonal crystal structure that occurs at high temperatures. Calcite is the most stable polymorph, and at low temperatures, it is insoluble when compared to aragonite. As a result, it is mostly employed in HAp synthesis than aragonite [17].

HAp preparation: the hydroxyapatite was synthesized using the wet chemical precipitation method. The calcium precursor was derived from calcite and the phosphate precursor from diammonium hydrogen phosphate. A quantity of $5.7 \mathrm{~g}$ of calcite was weighed and added to
$0.15 \mathrm{~cm}^{3}$ of distilled water to form calcite solution, and $5.9 \mathrm{~g}$ of diammonium hydrogen phosphate (DHP) was added to the same volume of distilled water as calcite at $\mathrm{pH} 8.1$ to form DHP solution. The DHP solution was added in a dropwise manner to the calcite solution and stirred for $2 \mathrm{~h}$ using a magnetic stirrer. The mixture was allowed to age for $12 \mathrm{~h}$. The mixture was then filtered, and the filtrate dried in an oven at $100{ }^{\circ} \mathrm{C}$ for $2 \mathrm{~h}$ to obtain hydroxyapatite without heat-treatment (HApS1) [17]. The HApS1 was kept in a furnace at $850{ }^{\circ} \mathrm{C}$ for $2 \mathrm{~h}$ and allowed to cool slowly in the furnace for $12 \mathrm{~h}$ to room temperature for annealing and normalizing to obtain hydroxyapatite with heat-treatment (HApS2).

HAp characterization: crystalline phases in HApS1 and HApS2 were identified by X-ray diffraction (XRD) using a diffractometer (PANalytical, Empyrean) with CuK $\alpha$ radiation $(\lambda=1.5406 \AA)$. The scan was performed at a speed of $2^{\circ} \cdot \mathrm{min}^{-1}$, and the patterns were matched to powder diffraction files (PDF) from the Joint Committee on Powder Diffraction Standards (JCPDS). Unit cell parameters were determined using a non-linear least square refinement program (UnitCell, CCP14), the crystallite size was calculated using the Scherer's equation (Eq. A), and crystallinity was determined using Eq. B:

$$
\text { Crystallite size }=\frac{0.94 . \lambda}{\beta \cdot \cos \theta}
$$

Crystallinity $=\frac{\text { Area of crystalline peaks }}{\text { Area of all peaks (amorphous+cristalline) }} .100$

where $\lambda=1.5418 \AA$ is the $\mathrm{X}$-ray wavelength, $\beta$ is the line broadening in radians, and $\theta$ is the Bragg angle. The Fourier-transform infrared spectrometer (FTIR, Bruker, Tensor 27) was used to determine the functional groups of materials. The analysis was performed over a wavenumber of 400 to $4000 \mathrm{~cm}^{-1}$.

In vitro bioactivity test: an in vitro assessment of the material was conducted in simulated body fluid (SBF) prepared using ISO 23317 protocol. A volume of $20 \mathrm{~mL}$ of SBF (pH 7.0) was poured into two separate falcon tubes. A quantity of $40 \mathrm{mg}$ of the prepared materials (HApS1 and HApS2) was immersed into $20 \mathrm{~mL}$ of SBF at $37^{\circ} \mathrm{C}$ for a period of 7 and 21 days under static conditions [18]. The mixtures were centrifuged, and the supernatant poured off for mineral (calcium and phosphate) concentration studies using an atomic absorption spectrometer (Perkin Elmer, PinAAcle 900t) and a spectrophotometer (Merck, Pharo 300), respectively. Materials were dried in an oven for $1 \mathrm{~h}$, and the bioactive apatite film determined using a scanning electron microscope (SEM, Thermo Sci., Phenom ProX) coupled with an energy dispersive spectroscope (EDS). The materials were analyzed at an accelerating voltage of $15 \mathrm{kV}$ at a working distance of $200 \mu \mathrm{m}$. Statistical analysis: materials were measured in triplicate in SBF; the results represent the means and the standard deviation as the error. Statistical significance was determined at a confidence level of $p>0.05$ using the Student t-test. 


\section{RESULTS}

XRD and FTIR of HApSI and HApS2: Fig. 1 shows the XRD patterns of a standard HAp [19], pre-immersion hydroxyapatite without heat-treatment (HApS1), and hydroxyapatite with heat-treatment (HApS2). From the PDF, standard HAp has main crystal planes (peaks) that occur between $31.8^{\circ}$ and $35^{\circ} 2 \theta$ positions, with the most intense peak at $31.8^{\circ}$ corresponding to the (211) reflection. HApS1 pattern showed the same peak positions as the standard HAp, whereas HApS2 showed a different pattern. The peak width (FWHM) of HApS2 was broader, with the most intense peak occurring at the (202) reflection. The width broadening corresponded to a smaller crystallite size (Table I). The (202) reflection of HApS2 was parallel to (211) reflection in HApS1, and this observation was indicative of a preferred orientation of the HApS2 crystal in the c-axis. The unit cell parameters obtained were $\mathrm{a}=9.9674 \AA$ and $\mathrm{c}=9.4291 \AA$ for $\mathrm{HApS} 1$, and $\mathrm{a}=9.4291 \AA$ and $\mathrm{c}=6.8796 \AA$ for HApS2. Thus (220) and (222) reflections showed a crystal growth in the c-axis, whereas (002) and (213) reflections in the a-plane reduced. The recrystallization and crystal growth resulted in increased crystallinity, $78.8 \%$ for HApS1, as compared to HApS2, which recorded 83.6\%.

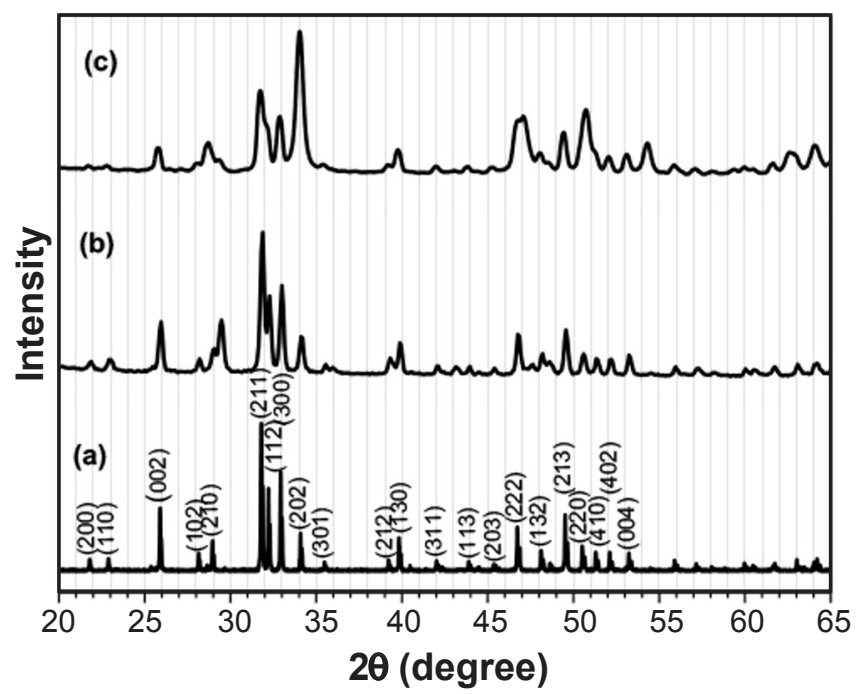

Figure 1: XRD patterns of standard HAp [19] (a), HApS1 (b), and HApS2 (c). In (c), broader peaks indicate smaller crystallite size, and intense (202), (222), and (220) peaks are indicative of preferred orientation.

[Figura 1: Padrões de DRX de HAp de referência [19] (a), HApS1 (b) e HApS2 (c). Em (c), picos mais largos indicam menor tamanho de cristalito e picos intensos (202), (222) e (220) indicam orientação preferencial.]

Fig. 2 shows the FTIR spectra for the standard HAp [19], HApS1, and HApS2. The functional groups present suggested the formation of HAp. Phosphate groups were found at wavenumbers of $563\left(v_{4}\right), 600\left(v_{4}\right), 963\left(v_{1}\right), 1029$ $\left(v_{3}\right)$, and $1098\left(v_{4}\right) \mathrm{cm}^{-1}$. The bond stretching vibration at $1406 \mathrm{~cm}^{-1}$ and vibrational bending at $874 \mathrm{~cm}^{-1}$ were assigned
Table I - Crystallite size (nm) from major planes for HApS1 and HApS2.

[Tabela I - Tamanho do cristalito $(\mathrm{nm})$ a partir de principais planos do HApS1 e HApS2.]

\begin{tabular}{ccc}
\hline Crystal plane & HApS1 & HApS2 \\
\hline$(211)$ & 30.5 & 12.2 \\
$(112)$ & 105.9 & 12.3 \\
$(300)$ & 118.6 & 19.8 \\
$(202)$ & 33.4 & 17.4 \\
Average & $72 \pm 23$ & $15 \pm 2$ \\
\hline
\end{tabular}

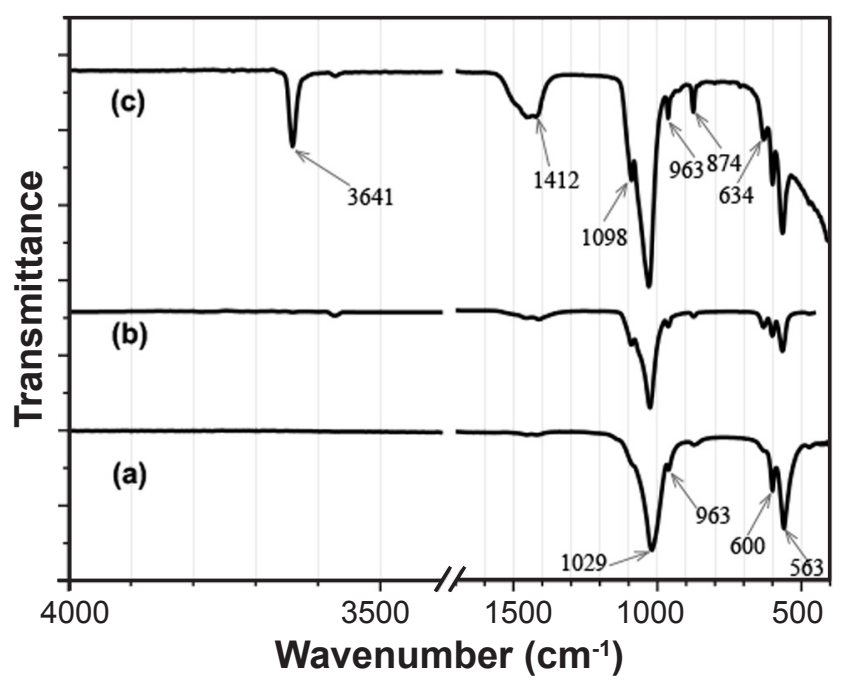

Figure 2: FTIR spectra of standard HAp [19] (a), HApS1 (b), and HApS2 (c). Intense bands at 1412 and $3641 \mathrm{~cm}^{-1}$ suggest that HApS2 is B-type carbonated hydroxyapatite.

[Figura 2: Espectros de FTIR do padrão HAp [19] (a), HApS1 (b) e HApS2 (c). Bandas intensas em 1412 e $3641 \mathrm{~cm}^{-1}$ sugerem que HApS2 é hidroxiapatita carbonatada do tipo B.]

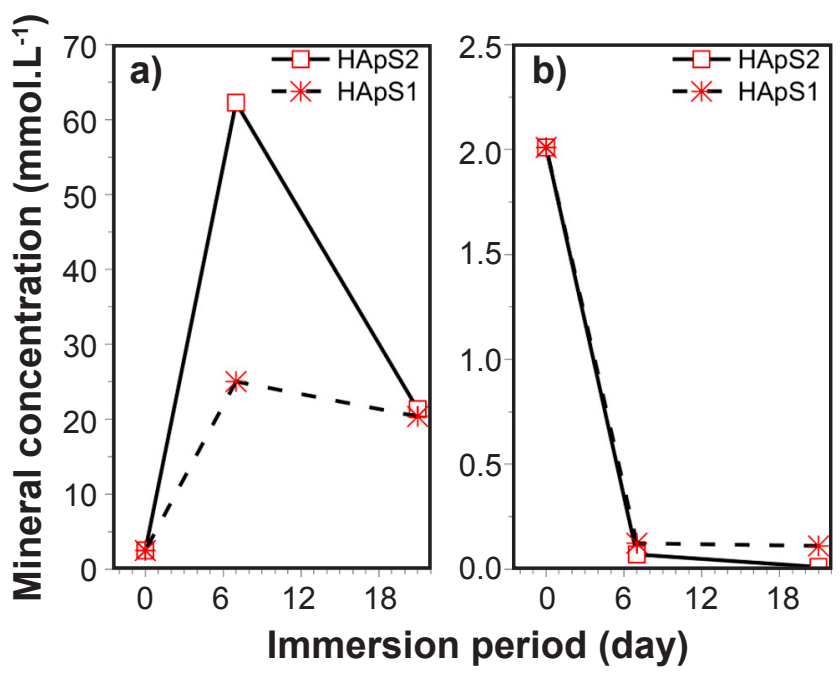

Figure 3: Calcium (a) and phosphate (b) levels in SBF for pre- and post-immersion for 7 and 21 days.

[Figura 3: Teores de cálcio (a) e fosfato (b) no SBF para pré-e pós-imersão por 7 e 21 dias.] 
a)
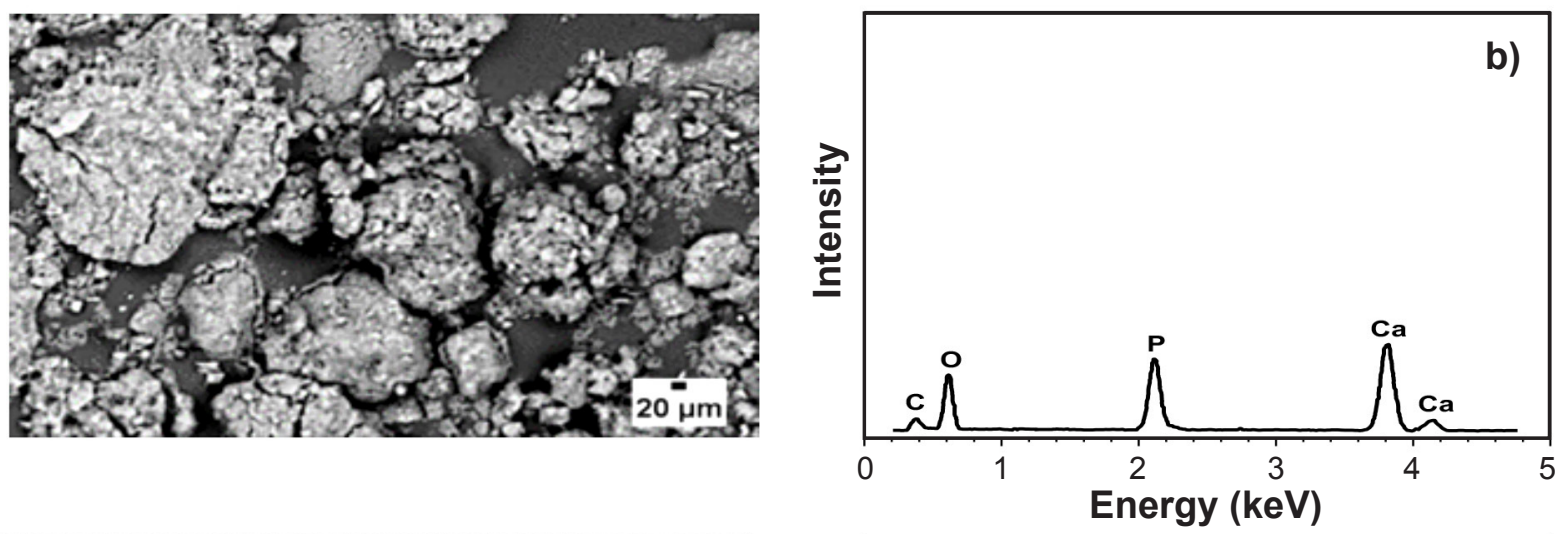

c)
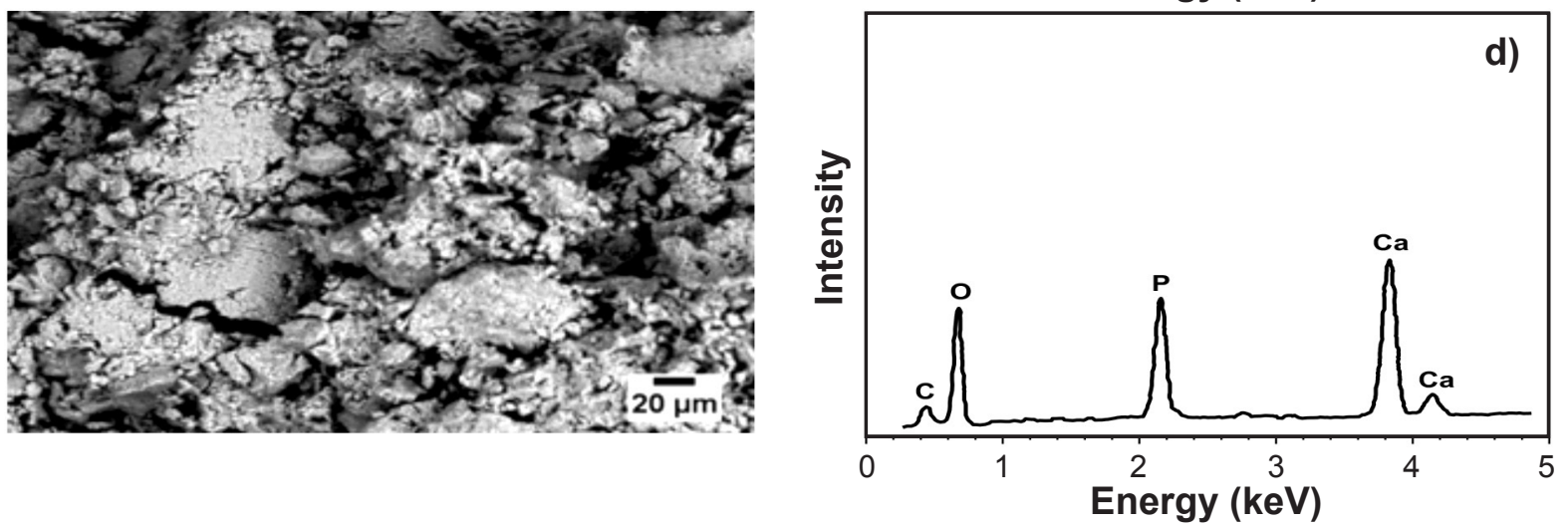

e)
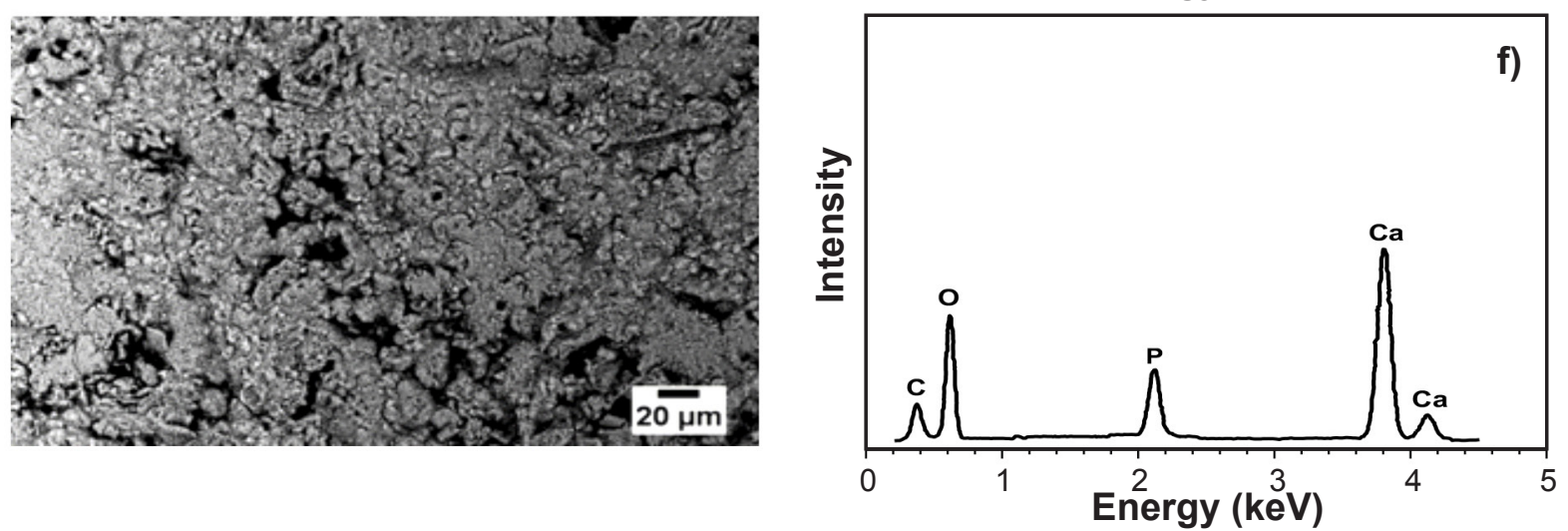

Figure 4: SEM images of HApS1 surface for pre-immersion (a) and post-immersion in SBF for 7 days (c) and 21 days (e), and EDS spectra corresponding to respective images $(\mathrm{b}, \mathrm{d}, \mathrm{f})$.

[Figura 4: Imagens de MEV da superfície de HApS1 de pré-imersão (a) e pós-imersão em SBF por 7 dias (c) e 21 dias (e), e espectros de EDS correspondentes às respectivas imagens $(b, d, f)$.]

to the carbonate groups, whereas the bands at 3641 and 634 $\mathrm{cm}^{-1}$ were related to structural -OH bonds in hydroxyapatite. The high intense bands from $\mathrm{OH}$ bonds in Fig. 2c is indicative of B-type carbonate substitution.

Mineralization and bioactivity of HApS1 and HApS2: Fig. 3 shows calcium and phosphate mineral levels in SBF (pH 7.0) for pre- and post-immersion (7 and 21 days). For post-immersion for 7 days, calcium level (Fig. 3a) for HApS2 significantly $(\mathrm{p}<0.05)$ increased from $2.48 \pm 0.01$ to $62.25 \pm 0.05$ mmol.L $\mathrm{L}^{-1}$ (pH 12.6) as compared to that of HApS1 (from $2.48 \pm 0.01$ to $25.03 \pm 0.03$ mmol.L $\mathrm{L}^{-1}, \mathrm{pH} 9.5$ ). On the other hand, phosphate level (Fig. 3b) decreased from $2.0 \pm 0.7$ to $0.12 \pm 0.03$ and $0.07 \pm 0.01 \mathrm{mmol} . \mathrm{L}^{-1}$ for HApS1 and HApS2, respectively. For post-immersion for 21 days, the mineral levels showed a significant $(\mathrm{p}>0.05)$ reduction from post-immersion for 7 days for both calcium and phosphate. HApS1 calcium concentration reduced from 25.03 \pm 0.03 to $20.38 \pm 0.01$ mmol. $\mathrm{L}^{-1}$ (pH 9.5), representing a $19.6 \%$ reduction. Similarly, HApS2 showed an immense significant reduction from $62.25 \pm 0.05$ to $21.34 \pm 0.01 \mathrm{mmol}^{-\mathrm{L}^{-1}}$ (pH $10.7)$ that indicated a $66 \%$ reduction. Phosphate mineral level reduction was $83 \%$ and $11 \%$ for HApS1 and HApS2, respectively.

Figs. 4 and 5 shows SEM images and EDS spectra of HApS1 and HApS2 for pre-immersion and post-immersion for 7 and 21 days in SBF. The surface of pre-immersion for HApS1 (Fig. 4a) showed chunks which characterize an irregular agglomerate and is representative of a number 
a)

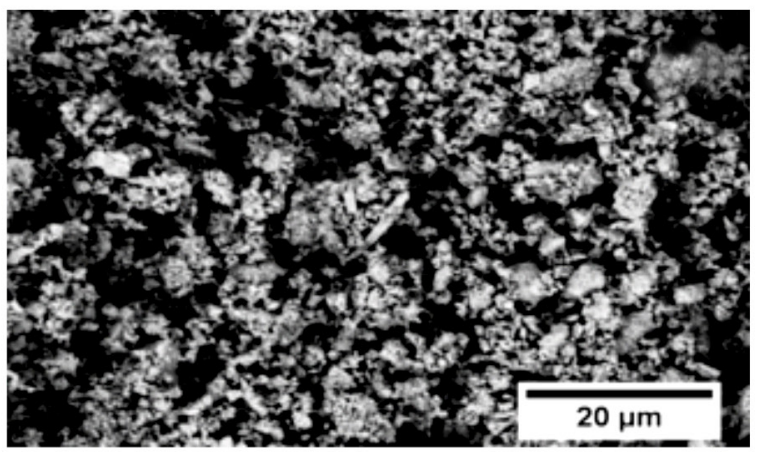

c)

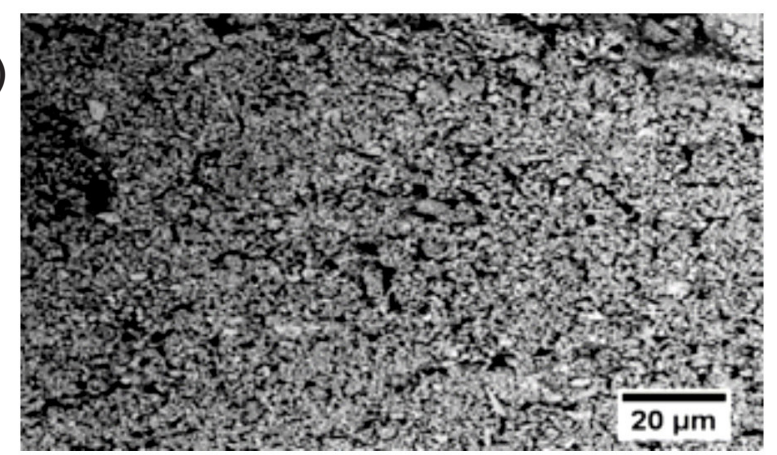

e)

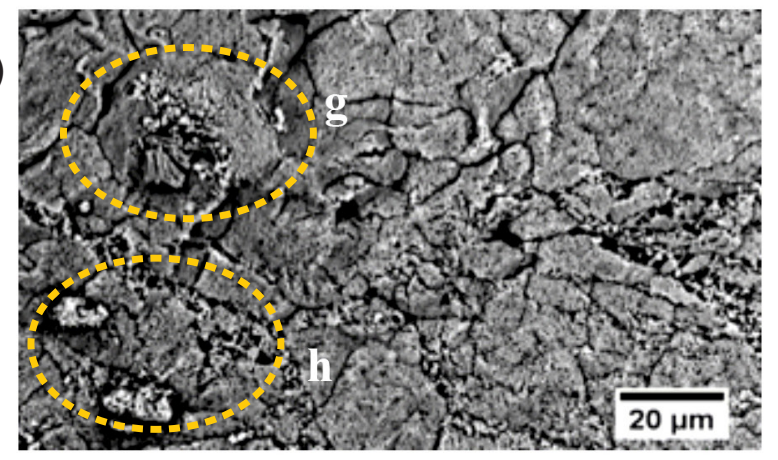

g)

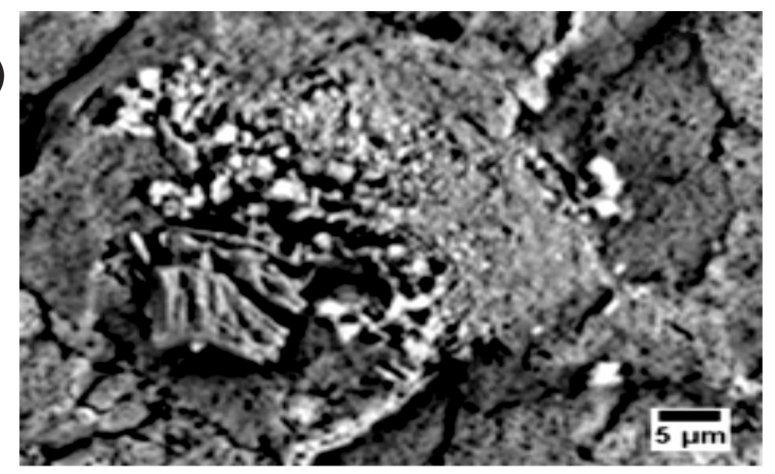

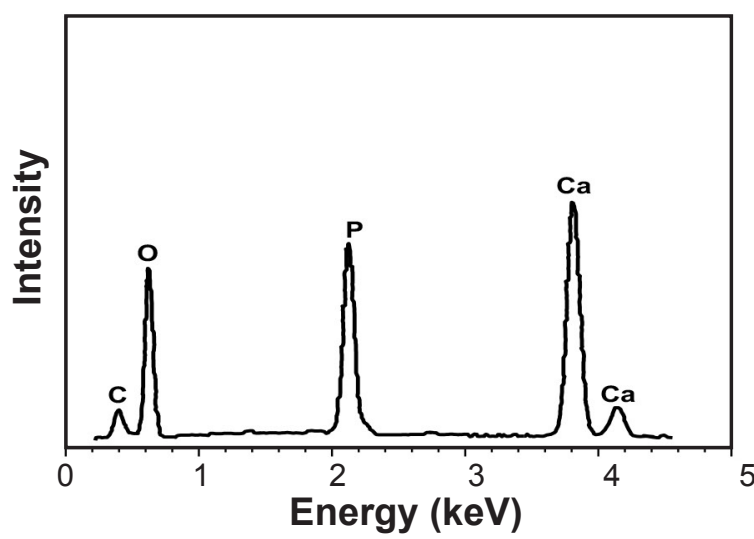

b)

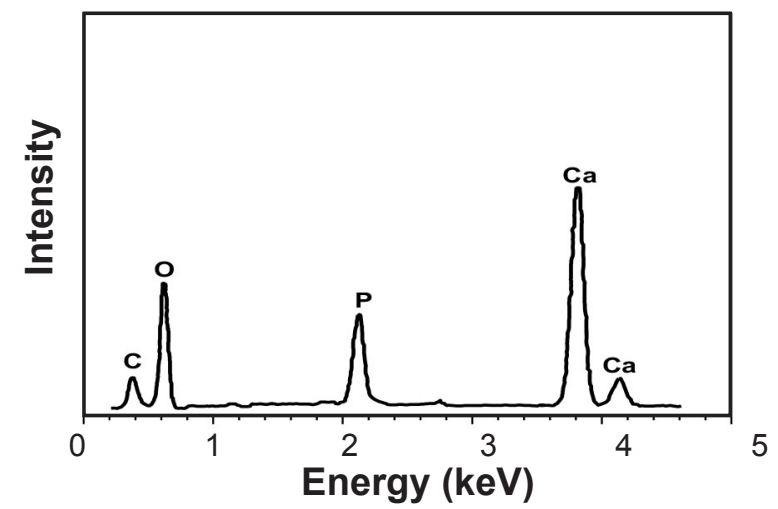

d)

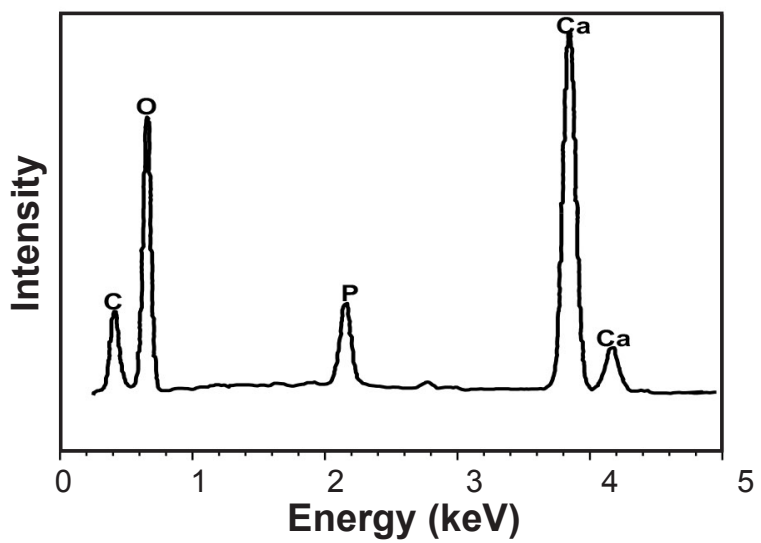

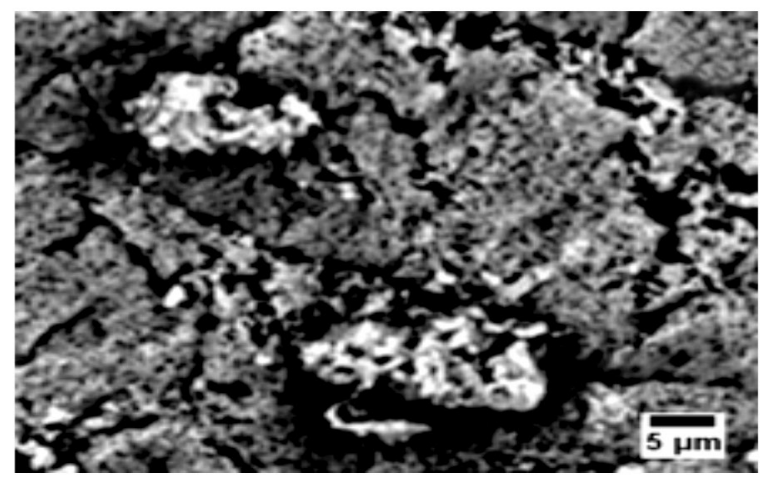

h)

Figure 5: SEM images of HApS2 surface for pre-immersion (a) and post-immersion in SBF for 7 days (c) and 21 days (e), and EDS spectra corresponding to respective images $(\mathrm{b}, \mathrm{d}, \mathrm{f})$. SEM images with high magnification $(\mathrm{g}, \mathrm{h})$ from regions indicated in (e) showing micro-wells, spheroids, and bundles, characteristics of carbonated apatite.

[Figura 5: Imagens de MEV da superficie de HApS2 de pré-imersão (a) e pós-imersão em SBF por 7 dias (c) e 21 dias (e), e espectros de EDS correspondentes às respectivas imagens $(b, d, f)$. Imagens de MEV com alta ampliação $(g, h)$ das regiões indicadas em (e) mostrando micropoços, esferóides e feixes, característicos da apatita carbonatada.] 
of nanoparticle size distributions [20]. This observation is in agreement with findings in similar studies of HAp synthesized using the chemical precipitation method [20, 21]. For post-immersion for 7 days, the surface showed chunks with more cohesion than in the pre-immersion surface (Fig. 4c). For post-immersion for 21 days, the micrographs showed initiation of microweb-like structure (Fig. 4e). The EDS spectra for post-immersion specimens (Figs. 4d and 4f) showed slight increases of calcium, phosphorus, and oxygen levels when compared to the pre-immersion specimen (Fig. 4b). The pre-immersion surface of HApS2 (Fig. 5a) showed few platelets and agglomeration of chunks with the elemental composition indicated by the EDS spectrum (Fig. 5b). For post-immersion for 7 days, the surface totally changed to form clusters of tiny spheroids (Fig. 5c). For post-immersion for 21 days (Fig. 5e), the surface was transformed into a crystalline morphology with a web-like structure, microwells along the grain boundaries, and spheroid bundles (Figs. 5g and 5h) [22]. The EDS spectra in Figs. 5d and 5f show increasing intensities of calcium, phosphorus, oxygen, and carbon levels.

\section{DISCUSSION}

The preferred orientation in HApS2 was due to the recrystallization of HApS1 crystals caused by the annealing and normalizing. The HApS1 crystals were oriented in more than one direction and showed growth in (200), (110), (002), and (300) planes. Similar behavior has been observed in literature during fluorination and heat-treatment with HAp resulting in diffraction peak shifting and a decrease in a-axis [23]. In Fig. 1b, the (211) and (112) crystallographic planes of HApS1 form a doublet, which is typical of crystalline hydroxyapatite. The doublet is, however, combined in HApS2 materials to form a highly crystalline HAp. Literature reports that heat-treatments could cause phase changes in HAp; thus, the plane doublet disappears and reduces the crystallinity [24]. Conversely, our heat-treatment method caused a phase change and crystal growth, which resulted in plane doublet disappearance and also increased the crystallinity. The heattreatment resulted in HAp material with great resemblance to biological apatite, which typically exhibits a hexagonal crystal structure of unit cell parameters $\mathrm{a}=\mathrm{b}=9.432 \AA$ and $\mathrm{c}=6.881 \AA$. The hexagonal phase with these parameters is the most frequently reported and consists of unconnected $\mathrm{PO}_{4}^{3-}$ tetrahedral with $\mathrm{Ca}^{2+}$ in the interstitial space and a chain of $\mathrm{OH}^{-}$ions along the c-axis to balance the unit cell charges $[25,26]$. The unit cell parameters reported for HApS2 and its corresponding crystallite size (nanoparticulate) demonstrated that the HApS2 possessed morphological and structural similarities to the human enamel apatite [27].

The FTIR spectra in Figs. $2 b$ and $2 c$ revealed HApS1 and HApS2 to be carbonated materials. Carbonated HAp has been reported to possess some similarity with bone apatite in terms of structural composition [6] and is one of the indicators of HAp with comparable bone apatite resemblance. The difference in the FTIR spectra was due to the unique $\mathrm{OH}$ band, which characterized the structure of HApS2 as compared to HApS1. Typically, two main carbonate substitutions (A-type and B-type) may occur in apatite. In our situation, the B-type appeared to be dominant compared to the A-type and was characterized by the substitution of $\mathrm{CO}_{3}^{2-}$ by $\mathrm{PO}_{4}^{3-}$, whereas in the A-type $\mathrm{CO}_{3}{ }^{2-}$ replaces $\mathrm{OH}^{-}$. The substitution depends on the thermodynamic condition of the reaction; the first is normally prepared at high temperature using solidgas reaction, whereas the latter is prepared by precipitation in an aqueous environment $[28,29]$. The pathway for the substitution in the unit cell is given by:

$$
\mathrm{Ca}_{10-\left(\frac{\mathrm{x}-\mathrm{y}}{2}\right)}\left(\mathrm{PO}_{4}\right)_{6-\mathrm{x}}\left(\mathrm{CO}_{3}\right)_{\mathrm{x}}(\mathrm{OH})_{2-\mathrm{y}}\left(\mathrm{CO}_{3}\right)_{\mathrm{y}}
$$

The boundary condition is $0<\mathrm{x}, \mathrm{y} \leq 1$ at $\mathrm{x}=0$ for A-type carbonate substitution, and $\mathrm{y}=0$ for B-type carbonate substitution. For upper boundaries, Formula $\mathrm{C}$ becomes Formulae D and E for A-type and B-type carbonate substitution, respectively:

$$
\mathrm{Ca}_{10.5}\left(\mathrm{PO}_{4}\right)_{6} \mathrm{OH}\left(\mathrm{CO}_{3}\right)
$$

$$
\mathrm{Ca}_{9.5}\left(\mathrm{PO}_{4}\right)_{5} \mathrm{CO}_{3}(\mathrm{OH})_{2}
$$

The intense $\mathrm{OH}^{-}$signature band we have reported in HApS2 represented the $\mathrm{CO}_{3}-\mathrm{OH}$ bonding as indicated in Formula E. Thus, it was in evidence that HApS2 was a B-type carbonate substitution. Conversely, the disappearance of the $\mathrm{OH}^{-}$band in HApS1 suggested A-type carbonate substitution. Literature reports human enamel to be B-type carbonate apatite $[27,29,30]$ and, thus, support the XRD revelation. The displaced calcium from the B-type substitution in HApS2 is what contributed to the crystallographic preferred orientation observed from the XRD patterns [31]. The displaced calcium was narrowed to a specific crystal direction during the annealing and normalizing. These were released in SBF during dissolution. The evidence was the high calcium level recorded for 7 days of immersion for HApS2 in SBF relative to that of HApS1. The high $\mathrm{pH}$ value of 12.6 after dissolution suggested that calcium mineral was in association with carbonate [32]. The solution reached a supersaturation and interacted with phosphate in solution to form amorphous calcium phosphate (ACP) [14]. The ACP formation was distinct in HApS2 due to the presence of more calcium in SBF; thus, the corresponding web-like morphology was indicative of nucleation of apatite film formation [20], which was initiated from the interaction between the calcium-rich ACP and the deficient calcium surface of the material after dissolution. The high reduction (66\%) of calcium mineral in SBF for 21 days from 7 days suggested that more calcium minerals were picked-up from the SBF, some to form the ACP structure, and some were adsorbed to the material surface through the hydroxyl and phosphate groups. The latter is reasonable since the $\mathrm{pH}$ of the solution reduced from 12.6 to 10.7. Additional evidence was the nearly zero concentration of phosphate in the SBF. The 
material surface formed calcium-poor ACP then interacted with the calcium-rich ACP to form apatite crystals. The crystalline morphology of HApS2 showed micro-wells, spheroids, and bundles [21], which are indicative of apatite growth. The HApS1 morphology for 21 days immersion was different from that of HApS2. SEM image showed no indication of apatite growth from the surface but rather suggested apatite nucleation. The supersaturation of calcium minerals was not attained and probably could be achieved if dissolution time was prolonged, as reported [28]. The high rise in calcium, phosphorus, carbon, and oxygen intensities in the EDS spectra in post-immersion for 21 days suggested the formation of calcium phosphate carbonate-rich apatite.

\section{CONCLUSIONS}

This study reported the successful preparation of bioactive hydroxyapatite (HAp) material from snail (Achatina achatina) shells and phosphate containing-solution by wet chemical precipitation and heat-treatment. The conditions under heattreatment were the most favorable for the synthesis of the bioactive material (HApS2) compared to the non-heat-treated material (HApS1). FTIR spectra showed both materials to be carbonated HAp, and XRD revealed a crystallographic preferred orientation on the c-axis of the HApS2 crystal with unit cell parameters $a=9.4291 \AA$ and $c=6.8796 \AA$ and crystallite size of $15 \pm 2 \mathrm{~nm}$. The in vitro mineralization and bioactivity assessment of the materials in simulated body fluid showed higher dissolution of calcium mineral in the bioactive material, HApS2 than HApS1, which was attributed to preferred orientation and deeply influenced the microstructure. The morphology showed web-like, microwells, spheroids, and bundles that identified biological apatite growth. The characteristics of the bioactive material (HApS2) resembled human enamel apatite and could, therefore, be used as a fast resorbing material with great potential for tooth repairs and implant surface coatings.

\section{ACKNOWLEDGMENT}

The authors acknowledge Mr. Solomon Kingsley Katu for his immense laboratory support during the experimental section.

\section{REFERENCES}

[1] S. Koutsopoulos, Langmuir 17 (2001) 8092.

[2] K.M.R. Nuss, B. von Rechenberg, Open Orthop. J. 2 (2008) 66.

[3] J.A. Rincón-López, J.A. Hermann-Muñoz, A.L. GiraldoBetancur, A. De Vizcaya-Ruiz, J.M. Alvarado-Orozco, J. Muñoz-Saldaña, Materials 11 (2018) 333.

[4] Y.Z. Wan, Y. Huang, C.D. Yuan, S. Raman, Y. Zhu, H.J. Jiang, F. He, C. Gao, Mater. Sci. Eng. C 27 (2007) 855.

[5] T. Kokubo, H. Takadama, Biomaterials 27 (2006) 2907.

[6] V. Mitran, R. Ion, F. Miculescu, M. Necula, A.-C. Mocanu,
G. Stan, I. Antoniac, A. Cimpean, Materials 11 (2018) 1097. [7] P.R. Schmidlin, R. Seemann, T. Filli, T. Attin, T. Imfeld, Oper. Dent. 32 (2007) 482.

[8] G.A.D. Deus, F. Martins, A.C.M.R. Lima, E.D. GurgelFilho, C.F. Maniglia, T. Coutinho-Filho, Pesq. Odont. Bras. 17 (2003) 119.

[9] M. Al-Mosawi, G.R. Davis, A. Bushby, J. Montgomery, J. Beaumont, M. Al-Jawad, Sci. Rep. 8 (2018) 14449.

[10] J.-H. Park, D.-Y. Lee, K.-T. Oh, Y.-K. Lee, K.-M. Kim, K.-N. Kim, Mater. Lett. 60 (2006) 2573.

[11] I. Antoniac (Ed.), "Bioceramics and biocomposites: from research to use in clinical practice", John Wiley Sons, Hoboken (2019).

[12] R.B. Heimann, J. Therm. Spray Technol. 25 (2016) 827.

[13] S.K. Nandi, A. Mahato, B. Kundu, P. Mukherjee, in: Adv. Tech. Bone Regen., A.R. Zorzi, J.B. de Miranda (Ed.), InTech (2016).

[14] H.-M. Kim, T. Himeno, T. Kokubo, T. Nakamura, Biomaterials 26 (2005) 4366.

[15] N. Eliaz, N. Metoki, Materials 10 (2017) 334.

[16] P. Choudhury, D.C. Agrawal, in: Nanomedicine, Elsevier (2012) 84.

[17] B.O. Asimeng, J.R. Fianko, E.E. Kaufmann, E.K. Tiburu, C.F. Hayford, P.A. Anani, O.K. Dzikunu, J. Asian Ceram. Soc. 6 (2018) 205.

[18] M. Czikó, E.-S. Bogya, R. Barabás, L. Bizo, R. Stefan, Open Chem. 11 (2013).

[19] B. Lafuente, R.T. Downs, H. Yang, N. Stone, in: Highl. Miner. Crystallogr., T. Armbruster, R.M. Danisi (Ed.), De Gruyter, Berlin (2015) 1.

[20] P. Oberbek, T. Bolek, A. Chlanda, S. Hirano, S. Kusnieruk, J. Rogowska-Tylman, G. Nechyporenko, V. Zinchenko, W. Swieszkowski, T. Puzyn, Beilstein J. Nanotechnol. 9 (2018) 3079 .

[21] K. Ramesh, M.Y. Hu, J. Thomsen, M. Bleich, F. Melzner, Nat. Commun. 8 (2017) 1709.

[22] N. Mohan, R. Palangadan, H. Varma, Ceram. Int. 42 (2016) 17259.

[23] R. Murugan, T.S. Sampath Kumar, K. Panduranga Rao, Mater. Lett. 57 (2002) 429.

[24] R.B. Heimann, J. Therm. Spray Technol. 27 (2018) 1212.

[25] R. Astala, M.J. Stott, Chem. Mater. 17 (2005) 4125.

[26] J.C. Elliot, R.M. Wilson, S.E.P. Dowker, Adv. X-Ray Anal. 45 (2002) 172.

[27] O.V. Frank-Kamenetskaya, in: Miner. Adv. Mater. I, S.V. Krivovichev (Ed.), Springer, Berlin (2008) 241.

[28] M. Jemal, in: Phosphoric acid ind. probl. solut., M.S. Wiener, B. Valdez (Ed.), InTech (2017).

[29] C. Combes, S. Cazalbou, C. Rey, Minerals 6 (2016) 34.

[30] H. Madupalli, B. Pavan, M.M.J. Tecklenburg, J. Solid State Chem. 255 (2017) 27.

[31] J. Fu, C. He, B. Xia, Y. Li, Q. Feng, Q. Yin, X. Shi, X. Feng, H. Wang, H. Yao, Sci. Rep. 6 (2016) 23509.

[32] B. Chen, F. Wang, J. Shi, F. Chen, H. Shi, Minerals 9 (2019) 436.

(Rec. 29/10/2019, Rev. 02/03/2020, 08/04/2020, Ac. $11 / 04 / 2020)$ 